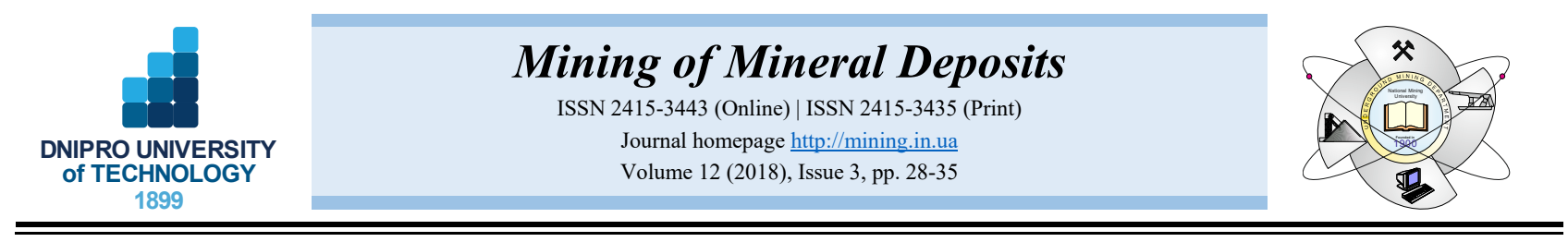

UDC 622.78(045):622.02:543.226

https://doi.org/10.15407/mining12.03.028

\title{
STUDY OF THE PLASMA FLOW INTERACTION WITH THE BOREHOLE SURFACE IN THE PROCESS OF ITS THERMAL REAMING
}

\author{
O. Voloshyn ${ }^{1}$, I. Potapchuk ${ }^{1}$, O. Zhevzhyk ${ }^{2 *}$, V. Yemelianenko ${ }^{1}$, \\ V. Horiachkin ${ }^{2}$, M. Zhovtonoha ${ }^{2}$, Ye. Semenenko ${ }^{1}$, L. Tatarko ${ }^{3}$ \\ ${ }^{1}$ Institute of Geotechnical Mechanics named after M.S. Polyakov of the National Academy of Sciences of Ukraine, Dnipro, Ukraine \\ ${ }^{2}$ Dnipropetrovsk National University of Railway Transport named after academician V. Lazaryan, Dnipro, Ukraine \\ ${ }^{3}$ Ukrainian State University of Chemical Technology, Dnipro, Ukraine \\ *Corresponding author: e-mail zvzk@ukr.net, tel. +380976778455
}

\begin{abstract}
Purpose. Study of the plasma flow interaction with the borehole surface in the process of its thermal reaming for determination of transient temperature distribution along the borehole surface and the average coefficient of heat transfer from the plasma flow to the borehole surface.

Methods. Experimental study of the plasma flow interaction with the flange union with internal lateral surface simulating the rock surface in a borehole has been carried out. The essence of the experimental study is in measuring temperature of the flange union external side while the plasma flowing inside the flange union. To measure temperature on the external surface of the flange union, a chromel-alumel thermocouple with thermoelectrodes of $1.2 \mathrm{~mm}$ in diameter was used. In experimental research, plasma flows out through a nozzle directly to the flange union made of copper. The parameters of the flange union and the nozzle of plasmatron are geometrically similar.

Findings. Experimental data are processed as a relationship between the temperature of the copper flange union lateral surface, i.e. borehole surface, and the time of the copper flange union heating by the heat carrier. Experimental data are processed as a dependence of temperature of the tin pipe side surface, i.e. surface of the borehole, on the location of temperature measurement point along the tin pipe and the time of the tin pipe heating by the heat carrier.

Originality. Physical simulation modeling of the heat carrier (low temperature plasma) flow interaction with the borehole surface simulated by the copper flange union and the tin pipe in a certain range of geometrical parameters of the copper flange union, tin pipe and the plasmatron nozzle as well as thermophysical properties of the heat carrier assumed in accordance with geometrical similarity to the technological and design parameters of the plasmatron and borehole diameter before the beginning of thermal reaming process.

Practical implications. Methodology of experimental research of the heat carrier (low temperature plasma) flow interaction with the borehole surface that was simulated by the copper flange union of the tin pipe is developed. The results of the influence by high-temperature heat carrier jets on the processes of fragile rock destruction are rather useful in the borehole drilling processes.
\end{abstract}

Keywords: borehole, rocks destruction, thermal reaming, plasma, heat transfer coefficient, flange union

\section{INTRODUCTION}

Taking into account productivity and expenditures for various methods of borehole drilling and reaming, thermal methods of rock destruction are of the most interest. Appropriacy of applying certain thermal methods for rock destruction is stipulated by a wide range of facilities to implement heating or cooling processes for rock masses. Forms of thermal effect on the rock have a unified physical basis, i.e. change of the potential of power connections (Germanovich, 1997). Stresses of thermal expansion of rock minerals are proportional to the thermal expansion coefficient of minerals, Young's modulus, and heating temperature. Since Young's modulus and thermal expansion coefficient of rock minerals take different values, certain structural thermal stresses occur within the rock while its heating apart from the stresses stipulated by the temperature gradient development; those stresses reach maximum values at the boundaries of mineral grains. Therefore, most of thermal rockdestruction products detach from the rock mass along the grain boundaries of minerals (Höser \& Rudolf von Rohr,

(C) 2018. O. Voloshyn et al. Published by the Dnipro University of Technology on behalf of Mining of Mineral Deposits.

This is an Open Access article distributed under the terms of the Creative Commons Attribution License (http://creativecommons.org/licenses/by/4.0/),

which permits unrestricted reuse, distribution, and reproduction in any medium, provided the original work is properly cited. 
2018). When thermal methods of rock destruction are applied, then the destruction products detach from the rock mass under the effect of the shearing and tensile thermal stresses. It is known that the limit of shearing and tensile strength is approximately $7-10$ times less than the limit of the compression strength. Thus, a thermal method of rock destruction is the most energy-saving one (Klyushnik \& Osenniy, 2014). While temperature increasing within a heating area along with the strength and aggregate hardness decreasing, a reduction of rock fragility is observed making it possible to use thermal methods of rock destruction effectively not only during borehole drilling processes but also in terms of borehole reaming (Osenniy \& Osennyaya, 2012). Thermal methods are the most efficient ones for borehole reaming, in particular, the techniques involving gas-jet heating of rock and arc electrical discharge to heat the rock.

Plasma burners have following advantages:

- wider adjustment range to control thermal parameters and jet power concentration (Ishchenko \& Osenniy, 2012);

- reduced amounts of hazardous gases emission $(\mathrm{Bu}-$ lat, Voloshyn, \& Zhevzhik, 2013);

- simplified system of the automation and remote control for the thermal tool compactness (Bulat, Voloshyn, \& Zhevzhik, 2013);

- fissure propagation at significant depth in the process of thermal destruction of rocks (Voloshyn, Potapchuk, \& Zhevzhyk, 2016);

- great values of the heat transfer coefficient and heat flux from a heat carrier to the borehole surface (Voloshyn, Potapchuk, \& Zhevzhyk, 2016).

It should be noted that the efficiency of thermal fragile rock destruction grows along with rock hardness increase, and expenditures for the process implementation tend to be reduced. The highest efficiency of a thermal method for rock destruction is observed while expanding boreholes driven in well-drillable rocks within rather solid rock masses.

A common feature of the known alternatives of technical solutions as for the application of thermal tools with an arc electrical discharge for rock destruction is a stream of low-temperature plasma outflowing from one or several nozzles in parallel or at a certain angle to the borehole axis.

The analysis of scientific sources demonstrates that, in terms of the known devices with an arc electrical discharge for rock destruction, the ranges of operating performance of thermal tools, effective modes of heating, mechanical loading, and fragile rock destruction were determined mostly experimentally.

The vast majority of the known experimental studies deals with the determination of time and temperature values of rock destruction.

Paper (Wilkinson \& Tester, 1993) presents average values of heat transfer coefficient from a heat carrier to the rock surface obtained experimentally; however insufficient attention is paid to the gas dynamics of the flow and interaction of heat carrier jet with the borehole surface.

Paper (Rauenzahn \& Tester, 1989) contains the values of heat carrier pressure on the rock surface; however, there is no information concerning the velocity of a heat carrier along the rock surface and average or local heat transfer coefficient.

Paper (Yan, 2013) provides data on the velocity of a heat carrier at the nozzle outlet - its value is up to $120 \mathrm{~m} / \mathrm{s}$ that could be compared with the velocity of plasma flow at the nozzle outlet of a plasmatron; however, in this case, incompressible liquid is used as a heat carrier. That makes it impossible to use the results of the experimental studies to determine heat transfer coefficient from a plasma jet to the rock surface.

Paper (Rauenzahnf \& Tester, 1991) applies highspeed (Mach number within the range of $2-5$ ) and high-temperature $\left(300-1100^{\circ} \mathrm{C}\right)$ jets of a heat carrier for fragile rock destruction. However, a heat carrier outflew from a nozzle in a pulse mode, and the efficiency of rock destruction depended on the excessive pressure of the jet on the borehole surface being within the range of $5-20 \mathrm{MPa}$.

The process of fragile destruction is provided by comparatively small $(4-10) \cdot 10^{3} \mathrm{~kW} / \mathrm{m}^{2}$ but concentrated enough heat fluxes with a heavy radial gradient. Borehole reaming rate depends exclusively on a heat flux; functional dependence of the rate is expressed exponentially (Poluianskyi, 1985).

The value of Young's modulus of the rock plays an important role in the process of thermal stresses distribution within the rock, e.g. at the temperature of $4500^{\circ} \mathrm{C}$ Young's modulus of granite and limestone decreases substantially after thermal influence on their surface during 10 seconds, and cracks are formed on the surface.

Few publications are devoted to the issues of the experimental studies of gas dynamics and plasma dynamics of the jets, used as a heat carrier for thermal methods of rock destruction.

Features of the available experimental studies allow determining velocity of a heat carrier along the borehole surface and values of the heat transfer coefficient only for the conditions indicated in those publications.

Efficiency of thermal methods of rock destruction is defined by a heat flux transferred from a heat carrier to the rock surface. Heat flux can be increase owing to the rise in a heat carrier temperature or heat transfer coefficient. Thus, application of high-speed jets of a heat carrier seems to be rather prospective in the processes of fragile rock destruction.

Since the available results of experimental studies are not sufficient to solve the tasks of the paper, it is required to carry out own experimental study of the interaction of high-speed heat carrier jets with the borehole surface.

\section{METHODS}

The paper represents experimental study of the interaction of high-speed plasma jets with a flange union which internal side surface simulated rock surface in the borehole. Experimental study involves two stages.

Stage one dealt with the temperature change of the external side surface of a flange union depending on the time of its heating. During the experimental study, a plasma jet flows out through a nozzle directly into the flange union made of copper (Fig. 1). 


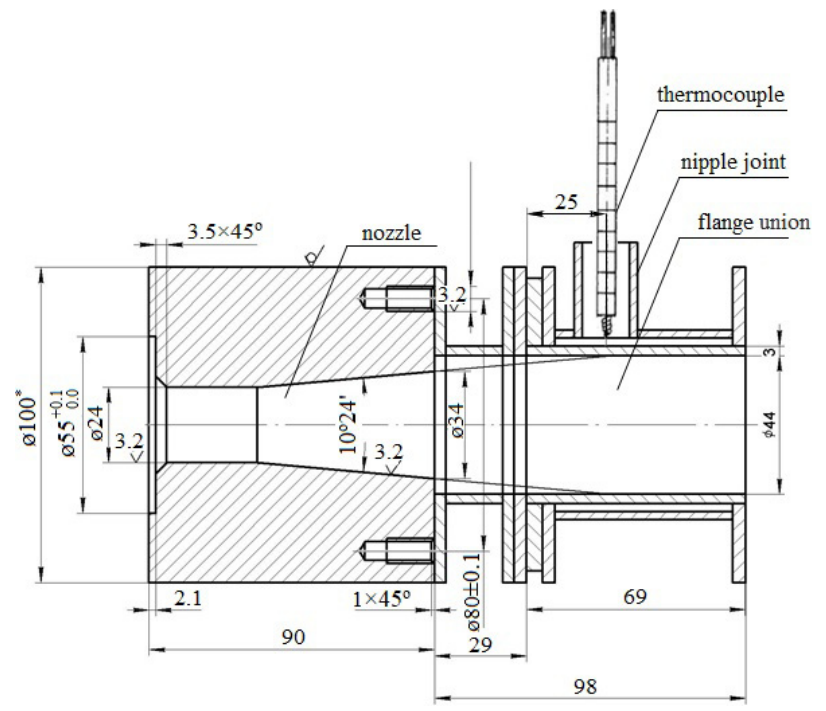

Figure 1. Nozzle of the plasmatron and a flange union

Duration of the plasmatron operation, i.e. duration of the flange union heating, was 37 seconds. Initial temperature of a flange union was $30^{\circ} \mathrm{C}$. At the end of the heating process, external surface temperature of a flange union reached $346^{\circ} \mathrm{C}$. When plasmotron was switched off, air purging through flange union was performed.

To measure temperature at the external surface of the flange union, a chromel-alumel thermocouple was used with thermoelectrodes of $1.2 \mathrm{~mm}$ in diameter.

Basic permissible error while temperature measuring within the range of $-40 \ldots+375^{\circ} \mathrm{C}$ is within $\pm 1.5^{\circ} \mathrm{C}$. Relative error of the measurement up to the temperature of $300^{\circ} \mathrm{C}$ is equal to $1.3 \%$; if it is up to the temperature of $600^{\circ} \mathrm{C}$, then it is $0.88 \%$. A thermocouple was located in a nipple joint of $15 \mathrm{~mm}$ in diameter (Fig. 1). Contact of thermocouple with external side surface of the flange union was provided owing to elastic deformation of the thermocouple.

Essence of the experimental study is in the temperature measurement of the external side of the flange union when plasma stream flows inside the flange union.

Temperature values of the external side surface of the flange union obtained experimentally are necessary for the determination of the heat transfer coefficient from the plasma jet to the internal side of the flange union that simulates rock surface in a borehole.

Table 1 represents values of the parameters of the experimental study analyzing plasma stream interaction with the flange union.

Table 1. Values of the experimental study parameters

\begin{tabular}{lc}
\hline \multicolumn{1}{c}{ Parameter } & Value \\
\hline Thermal power of plasma $Q, \mathrm{~kW}$ & 45 \\
Air flow rate $G_{\text {air }}, \mathrm{kg} / \mathrm{s}$ & 0.006 \\
Internal diameter of the flange union $d_{\text {int }}, \mathrm{m}$ & 0.044 \\
Wall thickness of the flange union $\delta, \mathrm{m}$ & 0.003 \\
Length of the flange union $l_{f l}, \mathrm{~m}$ & 0.098 \\
Length of the plasmatron nozzle $l_{\text {noz }}, \mathrm{m}$ & 0.09 \\
\hline
\end{tabular}

Geometrical parameters of the flange union and plasmatron nozzle were taken in accordance with geometrical similarity to the technological and design pa- rameters of the plasmatron and borehole diameter before the beginning of thermal reaming process.

Stage two of the experimental study involved analysis of the temperature distribution of the external side surface of a tin pipe along its length depending upon the period of the pipe heating. Duration of the plasmatron operation, i.e. period of the tin pipe heating, was 35 seconds. Initial temperature of the tin pipe was $30^{\circ} \mathrm{C}$. At the end of the heating process, external surface temperature of the tin pipe reached $823^{\circ} \mathrm{C}$. When plasmotron was switched off, air purging through the tin pipe was performed.

To measure temperature at the external surface of the tin pipe, four chromel-alumel thermocouples (their characteristics were shown before) were applied. Thermocouple junction point was pressed to the external surface of the tin pipe by clamps that embraced the pipe across the heat-insulating plate lining made of mullite.

Essence of the experimental study is in the temperature measurement of the external side of the tin pipe when plasma stream flows inside the flange union.

Table 2 represents values of the parameters of the experimental study analyzing plasma stream interaction with the tin pipe.

Table 2. Values of the experimental study parameters

\begin{tabular}{lc}
\hline \multicolumn{1}{c}{ Parameter } & Value \\
\hline Thermal power of plasma $Q, \mathrm{~kW}$ & 45 \\
Air flow rate $G_{\text {air }}, \mathrm{kg} / \mathrm{s}$ & 0.006 \\
Internal diameter of the tin pipe $d_{\text {int }}, \mathrm{m}$ & 0.105 \\
Wall thickness of the tin pipe $\delta, \mathrm{m}$ & 0.0005 \\
Length of the tin pipe $l_{f l}, \mathrm{~m}$ & 1.0 \\
Length of the plasmatron nozzle $l_{\text {noz }}, \mathrm{m}$ & 0.09 \\
Distance from the plasmatron nozzle & 0.2 \\
section to the first measurement point, $\mathrm{m}$ & \\
$\begin{array}{l}\text { Spacing between the thermocouples } \\
\text { (measurement points) along the tin pipe, } \mathrm{m}\end{array}$ & 0.2 \\
\hline
\end{tabular}

Geometrical parameters of the tin pipe and plasmatron nozzle were taken in accordance with geometrical similarity to the technological and design parameters of the plasmatron and borehole diameter before the beginning of thermal reaming process.

\section{RESULTS AND DISCUSSION}

Figure 2 shows the temperature of the external side surface of the flange union in the process of its heating by the plasma stream flowing inside the flange union.

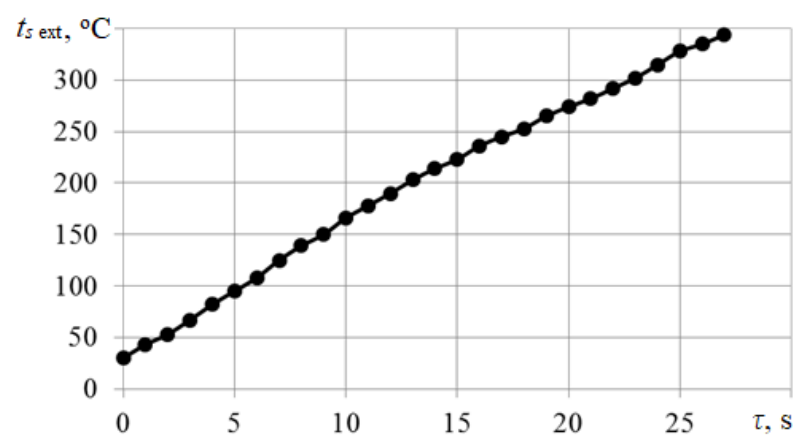

Figure 2. Temperature change of the external surface of the flange union depending its heating time 
Figure 2 demonstrates that during the heating period of the flange union, being not more than 27 seconds, the temperature increases according to linear law.

Figure 3 shows the dependence of temperature of the external side surface of the tin pipe on its heating time at four measurement points. Figure 3 indicates that during the heating period of the tin pipe, being not more than 35 seconds, temperature rises according to linear law at point 1 , point 2 , and point 3 ; as for point 4 , temperature rises here according to the law close to a power one.

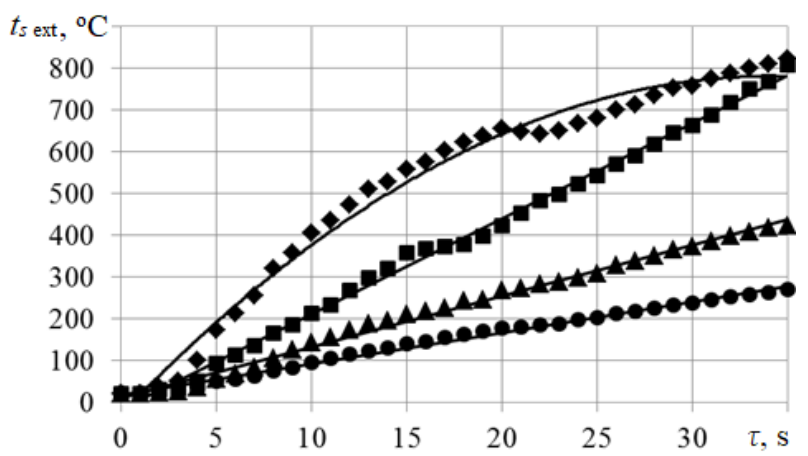

Figure 3. Dependence of temperature change of the side tin pipe surface upon its heating time: $\bullet$ distance from the plasmatron nozzle section is $0.2 \mathrm{~m}$ (point 1); - distance from the plasmatron nozzle section is $0.4 \mathrm{~m}$ (point 2); $\Delta$ distance from the plasmatron nozzle section is $0.6 \mathrm{~m}$ (point 3); - distance from the plasmatron nozzle section is $0.8 m$ (point 4)

Figures 4 and 5 show 2-D and 3-D views of temperature distribution of the plasma flow along the tin pipe respectively.

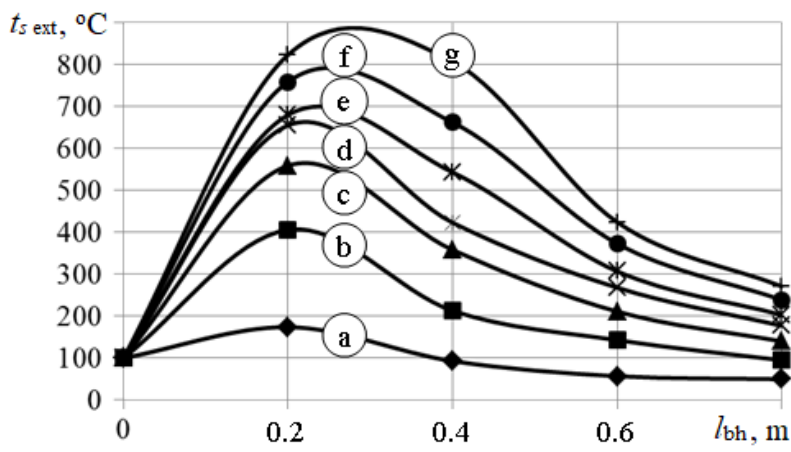

Figure 4. Temperature distribution of the plasma flow along the tin pipe: (a) heating time of the internal side of the tin pipe $\tau=5 \mathrm{~s}$; (b) heating time of the internal side of the tin pipe $\tau=10 \mathrm{~s}$; (c) heating time of the internal side of the tin pipe $\tau=15 \mathrm{~s}$; (d) heating time of the internal side of the tin pipe $\tau=20 \mathrm{~s}$; (e) heating time of the internal side of the tin pipe $\tau=25 \mathrm{~s} ;(f)$ heating time of the internal side of the tin pipe $\tau=30 \mathrm{~s} ;(\mathrm{g})$ heating time of the internal side of the tin pipe $\tau=35 \mathrm{~s}$

Figure 6 shows a comparison of the experimental data on temperature distribution of the plasma flow along the tin pipe both for the conditions of the proper experimental research and for the conditions of the experimental studies mentioned in the scientific sources (Poluianskyi, 1985).

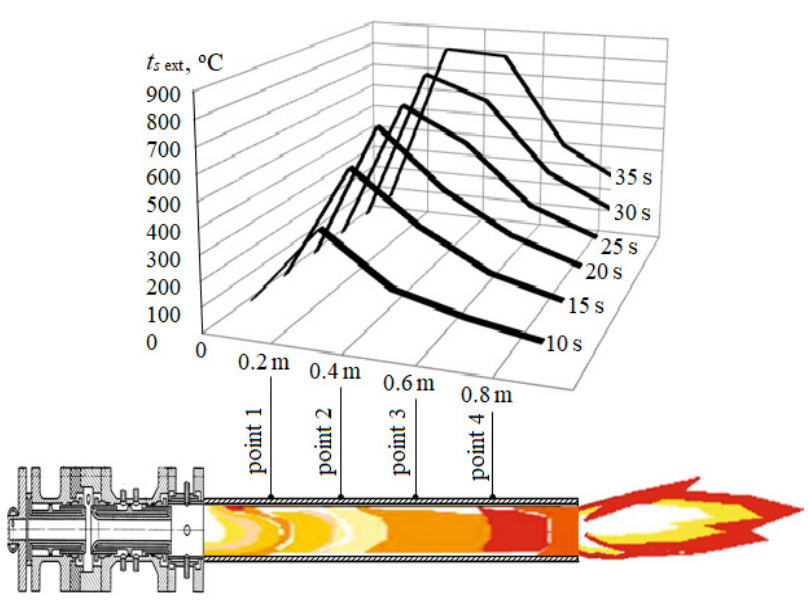

Figure 5. 3-D view of the temperature distribution of the external side of the tin pipe along its length depending upon the heating time of the internal side of the pipe

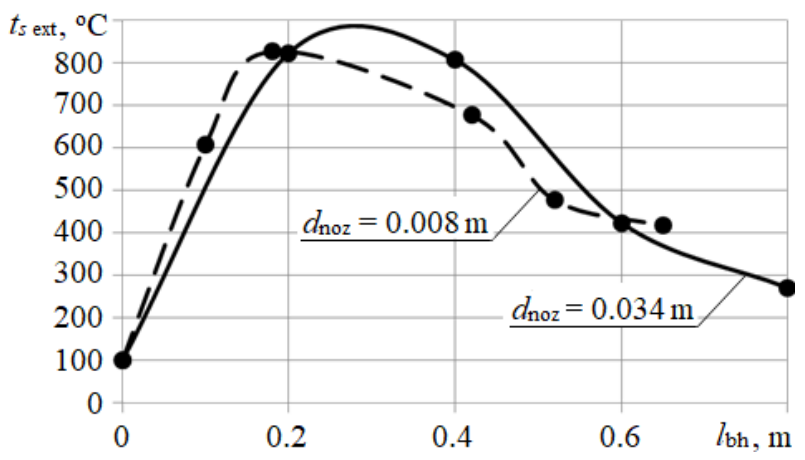

Figure 6. Comparison of the experimental data on the temperature distribution of the plasma flow along the tin pipe: - proper experimental research; --- other experimental research (Poluianskyi, 1985)

Analysis of Figures 5 and 6 allows drawing following conclusions:

- temperature of the external side of the tin pipe drops along with the increase in the distance from the plasmatron nozzle section to the point of the temperature measurement;

- nonuniformity of the tin pipe heating rises along with the increase in its heating time;

- maximum temperature value of the external side of the tin pipe moves away from the plasmatron nozzle section along with the increase in the heating time of the pipe that is confirmed by the experimental research (Poluianskyi, 1985).

Figure 6 makes it clear that within the range of interrelation $\frac{d_{p}}{d_{n o z}}=3.09-49.25$, similarity of the temperature distribution of the plasma flow along the pipe length is observed.

Heat flux from the flow of a heat carrier to the internal surface of the tin pipe is calculated as follows:

$q=\frac{Q}{F_{\text {sin }}}$,

where: 
$F_{\text {sin }}$ - area of the internal lateral surface of the nozzle and flange union.

Thermal power of plasma at the plasmatron outlet is:

$Q=U \cdot I \cdot \eta_{p l}+G_{\text {air }} \cdot c_{\text {mp air }} \cdot T_{\text {air } 0}$,

where:

$U$ - voltage of the plasmatron electrical arc;

$I$ - current rate of the plasmatron electrical arc;

$\eta_{p l}$ - thermal efficiency of the plasmatron;

$c_{m p}$ air - average isobaric heat capacity of air;

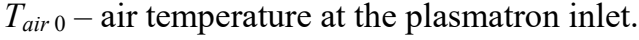

In the context of the experimental studies, average heat transfer coefficient from the plasma flow to the side surface of the borehole at the beginning of its heating was calculated according to following formula:

$\alpha_{a v 0}=\frac{q}{t_{p l}-t_{\sin 0}}$

where:

$t_{p l}$ - temperature of the plasma flow inside the flange union;

$t_{\sin 0}-$ initial temperature of the internal surface of the flange union.

Heat flux from the plasma flow to the side surface of the flange union was calculated according to expression (1).

Figure 7 shows the comparison of values of the average heat transfer coefficient from the plasma flow to the side surface of the borehole calculated on the basis of proper experimental results and criteria equations proposed by other authors. Figure 7 demonstrates that values of the average heat transfer coefficient from the plasma flow to the side surface of the borehole calculated according to equations (Kant, Rossi, Madonna, Höser, \& von Rohr, 2017) and (Kant et al., 2017) are by far less than the ones of the average heat transfer coefficient calculated on the basis of proper experimental research and according to expression (Kant et al., 2018) being as follows:

$\alpha=0.07\left(\rho_{p l} \cdot v_{p l} \cdot \frac{c_{p l}}{4190}\right)^{0.62}\left(\frac{\lambda_{p l} \cdot T_{w 0}}{4190 \cdot d_{i n}}\right)^{0.18}\left(\frac{T_{p l}}{T_{w 0}}\right)^{0.35}$,

where:

$\rho_{p l}$ - plasma density;

$v_{p l}$ - plasma velocity;

$c_{p l}$ - heat capacity of plasma;

$\lambda_{p l}-$ thermal conductivity of plasma;

$T_{w 0}$ - initial temperature of internal surface of the pipe.

Nevertheless, calculation according to the formula proposed in (Höser \& Rudolf von Rohr, 2018) being as follows:

$\alpha=5.7 c_{p l} \cdot \rho_{p l} \cdot v_{p l} \cdot \operatorname{Re}_{p l a v}^{-0.25} \cdot \operatorname{Pr}_{p l a v}^{0.43}\left(\frac{d_{p}}{l_{p}}\right)\left(\frac{d_{n o z}}{d_{p}}\right)^{0.25}$

where:

$d_{p}$ - tin pipe diameter;

$l_{p}-$ tin pipe length;

$d_{n o z}$ - nozzle diameter,

shows overestimated values of the heat transfer coefficient in comparison to the ones calculated on the basis of proper experimental research and according to formula (5).

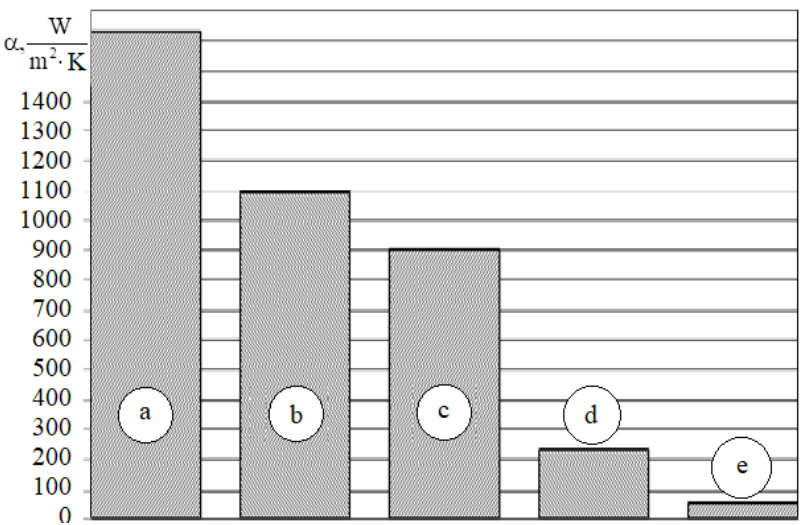

Figure 7. Comparison of heat transfer coefficient from the plasma flow to the lateral surface of the borehole determined both experimentally and theoretically: (a) calculation according to formula (4); (b) calculation according to formula (5); (c) proper experimental study; (d) calculation according to formula (Kant, Rossi, Madonna, Höser, \& von Rohr, 2017); (e) calculation according to formula (Kant et al., 2017)

Considerable difference of values of the average heat transfer coefficient might be stipulated by the following factors. In terms of their content, equations (Kant, Rossi, Madonna, Höser, \& von Rohr, 2017) and (Kant et al., 2017) are similar to the known criteria heat transfer equation under condition of turbulent flow of gases and liquids within the annular cross-section channels that is true for Prandtl numbers $\operatorname{Pr}_{f}=0.7-100$. However, Prandtl number for plasma in terms of the experimental research was equal to $\operatorname{Pr}_{p l}=0.513$ being beyond the Prandtl number range for which expressions (Kant, Rossi, Madonna, Höser, \& von Rohr, 2017) and (Kant et al., 2017) are valid.

Nusselt number calculated according to formula (Kant et al., 2017) is equal to $\mathrm{Nu}_{f}=5.1$ that proves suitability of formula (Kant et al., 2017) to calculate heat transfer coefficient only for non-ionized and nondissociated gases and liquids, since Nusselt number for such types of flow is within the range of $\mathrm{Nu}_{f}=3.66-4.36$.

It should be also mentioned that formulas (Kant, Rossi, Madonna, Höser, \& von Rohr, 2017) and (Kant et al., 2017) do not take into account temperatures of plasma and internal surface of the channel.

Formula (4) is valid only for the range of Reynolds numbers being $60<\mathrm{Re}_{\text {pl av }}<200$ at the determining temperature which is the average temperature of the plasma flow at the pipe inlet and outlet.

Equation (4) is valid only to evaluate average heat transfer coefficient from the plasma flow to the internal surface of the pipe that is proved by comparability of the average value of heat transfer coefficient calculated according to formula (5) and obtained experimentally by the authors of the paper.

\section{CONCLUSIONS}

Physical simulation modeling of thermal and technical aspects of the plasma flow interaction with borehole surface has been performed; results of the experimental research have been analyzed. 
Temperature values of the external side surface of the flange union obtained experimentally are necessary to determine heat transfer coefficient from the plasma jet to the internal surface of the flange union which simulates rock surface in a borehole.

According to the experimental results, following regularities have been determined:

- temperature of the external side of the tin pipe drops along with the increase in the distance from the plasmatron nozzle section to the point of the temperature measurement;

- nonuniformity of the tin pipe heating rises along with the increase in its heating time;

- maximum temperature value of the external side of the tin pipe moves away from the plasmatron nozzle section along with the increase in the heating time of the pipe.

Comparative calculation of the heat transfer coefficient from the plasma flow to the side surface of the borehole has been performed.

Comparability of the average value of heat transfer coefficient from a heat carrier to the internal side surface of the borehole determined by means of calculation and experimental studies has been confirmed.

\section{ACKNOWLEDGEMENTS}

The authors express their gratitude to V.P. Teplyi, Chief Project Designer at the Department of Vibropneumatic Transport Systems and Complexes of Institute of Geotechnical Mechanics named after M.S. Polyakov of the National Academy of Sciences of Ukraine, and S.V. Shniakin, Chief Engineer at the Department of Vibropneumatic Transport Systems and Complexes of Institute of Geotechnical Mechanics named after M.S. Polyakov of the National Academy of Sciences of Ukraine, for their valuable help during the experimental studies. The authors are also grateful to L.T. Kholiavchenko, Candidate of Technical Sciences (Ph.D), Senior Researcher at the Department of Rock Breaking Problems of Institute of Geotechnical Mechanics named after M.S. Polyakov of the National Academy of Sciences of Ukraine, for his valuable guidelines and comments relating to the experimental studies.

\section{REFERENCES}

Bulat, A., Voloshyn, O., \& Zhevzhik, O. (2013). Plasma reactor for thermochemical preparation of coal-air mixture before its burning in the furnaces. Annual Scientific-Technical Collection - Mining of Mineral Deposits, 39-44. https://doi.org/10.1201/b16354-9

Germanovich, L. (1997). Thermal spalling of rock. Advances Fracture Research, (6), 2771-2782.
Höser, D., \& Rudolf von Rohr, P. (2018). Experimental heat transfer study of confined flame jet impinging on a flat surface. Experimental Thermal and Fluid Science, (91), 166-174. https://doi.org/10.1016/j.expthermflusci.2017.10.014

Ishchenko, K.S., \& Osenniy, V.Ya. (2012). Investigation of the mechanism of destruction and structural changes in rocks at their thermal loading. Geo-Technical Mechanics, (107), 115-130.

Kant, M., Meier, T., Rossi, E., Schuler, M., Becker, D., Höser, D., \& von Rohr, P.R. (2017). Thermal spallation drilling - an alternative drilling technology for hard rock drilling. Oil Gas - European Magazine, 43(1), 23-25.

Kant, M., Rossi, E., Madonna, C., Höser, D., \& von Rohr, P.R. (2017). A theory on thermal spalling of rocks with a focus on thermal spallation drilling. Journal of Geophysical Research: Solid Earth, 122(3), 1805-1815. https://doi.org/10.1002/2016jb013800

Kant, M.A., Rossi, E., Duss, J., Amann, F., Saar, M.O., \& Rudolf von Rohr, P. (2018). Demonstration of thermal borehole enlargement to facilitate controlled reservoir engineering for deep geothermal, oil or gas systems. Applied Energy, (212), 1501-1509.

https://doi.org/10.1016/j.apenergy.2018.01.009

Klyushnik, V.G., \& Osenniy, V.Ya. (2014). Research of transitional characteristics of the plasma equipment in mine electric systems. Geo-Technical Mechanics, (119), 34-41.

Osenniy, V.Ya., \& Osennyaya, N.V. (2012). Kinetic parameters of physical and chemical processes of thermal transformations in rocks at a plasma chamber formation. GeoTechnical Mechanics, (97), 125-134.

Poluianskyi, S.A. (1985). To develop technology and embody tools for hard ores breaking by variable cross-section boreholes using plasma reamers. Part I. Report No. 01827023778. Moscow, Russian Federation: VNTI Centre.

Rauenzahn, R.M., \& Tester, J.W. (1989). Rock failure mechanisms of flame-jet thermal spallation drilling - theory and experimental testing. International Journal of Rock Mechanics and Mining Sciences \& Geomechanics Abstracts, 26(5), 381-399. https://doi.org/10.1016/0148-9062(89)90935-2

Rauenzahnf, R.M., \& Tester, J.W. (1991). Numerical simulation and field testing of flame-jet thermal spallation drilling -2 . Experimental verification. International Journal of Heat and Mass Transfer, 34(3), 809-818. https://doi.org/10.1016/0017-9310(91)90127-z

Voloshyn, O.I., Potapchuk, I.Yu., \& Zhevzhyk, O.V. (2016). Prospects of thermal tool with arc electric discharge usage in process of the rock breaking. Geo-Technical Mechanics, (131), 33-43.

Wilkinson, M.A., \& Tester, J.W. (1993). Experimental measurement of surface temperatures during flame-jet induced thermal spallation. Rock Mechanics and Rock Engineering, 26(1), 29-62. https://doi.org/10.1007/bf01019868

Yan, C., Deng, J., Yu, B., Li, W., Chen, Z., Hu, L., \& Li, Y. (2013). Borehole stability in high-temperature formations. Rock Mechanics and Rock Engineering, 47(6), 2199-2209. https://doi.org/10.1007/s00603-013-0496-2

\section{ДОСЛІДЖЕННЯ ВЗАЄМОДІЇ ПОТОКУ ПЛАЗМИ З ПОВЕРХНЕЮ СВЕРДЛОВИНИ У ПРОЦЕСІ ӤЇ ТЕРМІЧНОГО РОЗШИРЕННЯ}

\section{О. Волошин, І. Потапчук, О. Жевжик, В. Смельяненко,}

\section{В. Горячкін, М. Жовтонога, С. Семененко, Л. Татарко}

Мета. Дослідження взаємодії потоку плазми з поверхнею свердловини в процесі ії термічного розширення для визначення нестаціонарного розподілу температури вздовж поверхні свердловини та усередненого коефіцієнта тепловіддачі від потоку плазми до поверхні свердловини. 
Методика. В роботі виконано експериментальне дослідження взаємодії струмини плазми з фланцевим патрубком, внутрішня бокова поверхня якого імітувала поверхню гірської породи в свердловині. Сутність експерименту полягала у вимірюванні температури зовнішньої бічної поверхні фланцевого патрубка при течії плазмової струмини всередині патрубка. Для вимірювання температури на зовнішній поверхні фланцевого патрубка застосовувалась хромель-алюмелева термопара з термоелектродами діаметром 1.2 мм. В експериментальному дослідженні струмина плазми через сопло витікає безпосередньо у фланцевий патрубок, вироблений 3 міді. Дотримано геометричну подобу параметрів фланцевого патрубка та сопла плазмотрона.

Результати. Виконано обробку дослідних даних у вигляді залежності температури бічної поверхні мідного фланцевого патрубка, тобто поверхні свердловини, від часу нагрівання мідного фланцевого патрубка теплоносієм. Виконано обробку дослідних даних у вигляді залежності температури бічної поверхні жерстяної труби, тобто поверхні свердловини, від розташування точки вимірювання температури вздовж жерстяної труби та часу нагрівання жерстяної труби теплоносієм. Виявлено залежності зміни температури бічної поверхні жерстяної труби від часу іiї нагрівання; розподілу температури потоку плазми за довжиною жерстяної труби в залежності від діаметру жерстяної труби та діаметру вихідного отвору сопла плазмотрона; діапазон коефіцієнтів тепловіддачі від потоку плазми до поверхні свердловини.

Наукова новизна. Проведення фізичного імітаційного моделювання взаємодії потоку теплоносія, в якості якого виступає низькотемпературна плазма, з поверхнею свердловини у вигляді мідного фланцевого патрубка та жерстяної труби в певному діапазоні геометричних параметрів мідного фланцевого патрубка, жерстяної труби та сопла плазмотрона, а також теплофізичних характеристик теплоносія, які прийняті у відповідності до геометричної подоби технологічним і конструктивним параметрам плазмотрона та діаметра свердловин перед початком процесу термічного розширення.

Практична значимість. Розроблено методику експериментального дослідження взаємодії струмини теплоносія, в якості якого виступає низькотемпературна плазма, з поверхнею свердловини у вигляді мідного фланцевого патрубка жерстяної труби, яка імітувала свердловину. Отримані результати впливу високотемпературних струмин теплоносія в процесах крихкого руйнування гірських порід $є$ корисними при виконанні процесу буріння свердловин.

Ключові слова: свердловина, руйнування гірських порід, термічне розширення, плазма, коефіцієнт тепловіддачі, фланщевий патрубок

\title{
ИССЛЕДОВАНИЕ ВЗАИМОДЕЙСТВИЯ ПОТОКА ПЛАЗМЫ С ПОВЕРХНОСТЬЮ СКВАЖИНЫ В ПРОЦЕССЕ ЕЕ ТЕРМИЧЕСКОГО РАСШИРЕНИЯ
}

\author{
А. Волошин, И. Потапчук, А. Жевжык, В. Емельяненко, \\ В. Горячкин, Н. Жовтонога, Е. Семененко, Л. Татарко
}

Цель. Исследование взаимодействия потока плазмы с поверхностью скважины в процессе ее термического расширения для определения нестационарного распределения температуры вдоль поверхности скважины и усредненного коэффициента теплоотдачи от потока плазмы к поверхности скважины.

Методика. В работе выполнено экспериментальное исследование взаимодействия струи плазмы с фланцевым патрубком, внутренняя боковая поверхность которого имитировала поверхность горной породы в скважине. Сущность эксперимента заключалась в измерении температуры внешней боковой поверхности фланцевого патрубка при течении плазменной струи внутри патрубка. Для измерения температуры на внешней поверхности фланцевого патрубка применялась хромель-алюмелевая термопара с термоэлектродами диаметром 1.2 мм. В экспериментальном исследовании струя плазмы через сопло вытекает непосредственно во фланцевый патрубок, выполненный из меди. Соблюдено геометрическое подобие параметров фланцевого патрубка и сопла плазмотрона.

Результаты. Выполнена обработка опытных данных в виде зависимости температуры боковой поверхности медного фланцевого патрубка, то есть поверхности скважины, от времени нагревания медного фланцевого патрубка теплоносителем. Выполнена обработка опытных данных в виде зависимости температуры боковой поверхности жестяной трубы, то есть поверхности скважины, от расположения точки измерения температуры вдоль жестяной трубы и времени нагревания жестяной трубы теплоносителем.

Научная новизна. Проведение физического имитационного моделирования взаимодействия потока теплоносителя, в качестве которого выступает низкотемпературная плазма, с поверхностью скважины в виде медного фланцевого патрубка и жестяной трубы в определенном диапазоне геометрических параметров медного фланцевого патрубка, жестяной трубы и сопла плазмотрона, а также теплофизических характеристик теплоносителя, которые приняты в соответствии с геометрическим подобием технологическим и конструктивным параметрам плазмотрона и диаметра скважин перед началом процесса термического расширения.

Практическая значимость. Разработана методика экспериментального исследования взаимодействия струи теплоносителя, в качестве которого выступает низкотемпературная плазма, с поверхностью скважины в виде медного фланцевого патрубка жестяной трубы, которая имитировала скважину. Полученные результаты влияния высокотемпературных струй теплоносителя в процессах хрупкого разрушения горных пород будут полезными в процессе бурения скважин.

Ключевые слова: скважина, разрушение горных пород, термическое расширение, плазма, коэффициент теплоотдачи, фланцевый патрубок 


\section{ARTICLE INFO}

Received: 10 February 2018

Accepted: 18 July 2018

Available online: 10 August 2018

\section{ABOUT AUTHORS}

Oleksii Voloshyn, Doctor of Technical Sciences, Deputy Director of the Institute of Geotechnical Mechanics named after M.S. Polyakov of the National Academy of Sciences of Ukraine, 2a Simferopolska St, 49005, Dnipro, Ukraine. E-mail: OIVoloshyn1951@,nas.gov.ua

Iryna Potapchuk, Master of Engineering Sciences, Junior Researcher of the Department of Vibropneumatic Transport Systems and Complexes, Institute of Geotechnical Mechanics named after M.S. Polyakov of the National Academy of Sciences of Ukraine, 2a Simferopolska St, 49005, Dnipro, Ukraine. E-mail: IYPotapchuk@nas.gov.ua

Oleksandr Zhevzhyk, Candidate of Technical Sciences, Associate Professor of the Thermal Engineering Department, Dnipropetrovsk National University of Railway Transport named after academician V. Lazaryan, 2 Academika Lazaryana St, 49010, Dnipro, Ukraine. E-mail: zvzk@ukr.net

Volodymyr Yemelianenko, Candidate of Technical Sciences, Senior Researcher of the Department of Vibropneumatic Transport Systems and Complexes, Institute of Geotechnical Mechanics named after M.S. Polyakov of the National Academy of Sciences of Ukraine, 2a Simferopolska St, 49005, Dnipro, Ukraine. E-mail: VIEmelianenko@nas.gov.ua

Vadym Horiachkin, Candidate of Technical Sciences, Associate Professor of the Thermal Engineering Department, Dnipropetrovsk National University of Railway Transport named after academician V. Lazaryan, 2 Academika Lazaryana St, 49010, Dnipro, Ukraine. E-mail: vgora@ukr.net

Mykola Zhovtonoha, Candidate of Economic Sciences, Vice-Rector of the Dnipropetrovsk National University of Railway Transport named after academician V. Lazaryan, 2 Academika Lazaryana St, 49010, Dnipro, Ukraine. E-mail: znn.mail@gmail.com

Yevhen Semenenko, Doctor of Technical Sciences, Head of the Department of Mine Energy Complexes, Institute of Geotechnical Mechanics named after M.S. Polyakov of the National Academy of Sciences of Ukraine, 2a Simferopolska St, 49005, Dnipro, Ukraine. E-mail: evs_post@meta.ua

Larysa Tatarko, Candidate of Technical Sciences, Senior Instructor of the Physics Department, Ukrainian State University of Chemical Technology, 8 Haharina Ave., 49600, Dnipro, Ukraine. E-mail: larisa.tatarko@gmail.com 